\title{
PENERAPAN MANAJEMEN PERUBAHAN PADA RESTORAN \\ BARASENJA KOTA MALANG
}

\author{
$\underline{\text { Fitriyah Yuliani }}$ \\ Emai: fitriyahyuliani0101@gmail.com
}

\begin{abstract}
$\underline{\text { Latar belakang }}$
kemajuan globalisasi melibatkan pengembangan berbagai organisasi di berbagai negara, membawa persaingan ketat di setiap organisasi yang didirikan. Persaingan yang serius juga menjadi tolak ukur bagi sebuah organisasi untuk bisa menjadi sebuah organisasi yang baik. Salah satunya adalah organisasi yang bergerak di bidang makanan cepat saji (cheap food) dimana organisasi makanan cepat saji adalah organisasi yang sedang mengalami perkembangan yang semakin berkembang, salah satu contohnya adalah Bara Senja café ,dimulai dari segi produk, segmentasi pasar dan inovasi yang dikembangkan. Produk yang dibuat oleh suatu organisasi menjadi komponen penting dalam mendorong majunya suatu organisasi. untuk memenangkan persaingan suatu perusahaan , perusahaan harus terus berlomba-lomba dalam menghasilkan produk yang lebih baik yang ditunjukkan oleh kebutuhan pasar
\end{abstract}

\section{$\underline{\text { Latar belakang teori }}$}

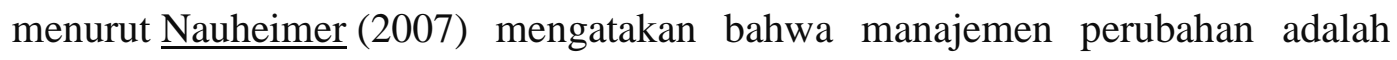
suatu proses, teknik, dan alat yang digunakan untuk mengelola proses perubahan pada sisi individu untuk mencapai suatu hasil yang dibutuhkan dan untuk menerapkan perubahan secara lebih efektif dengan agen perubahan, sistem, dan tim yang lebih luas.

Seperti yang diungkapkan Wibowo dalam buku "Managing change, pengantar manajemen ".Perubahan" dia berpendapat bahwa perubahan itu sendiri membuat 
sesuatu menjadi unik, perubahan adalah perubahan dari status sekarang suatu organisasi menuju keadaan ideal di kemudian hari.

Seperti yang ditunjukkan oleh Sonnenberg 1994, Perubahan terjadi setiap hari seperti menjalankan usaha seakan seperti biasanya adalah resep yang bisa memastikan kegagalan. Untuk berhasil, organisasi harus menerima perubahan. Tidaklah cukup jika organisasi hanya responsif terhadap perubahan. Organisasi harus mempelajari perubahan.

Menurut Drs H.M. Yani 2012, Organisasi yang perlu terus eksis dan memiliki citra positif di mata publik tidak akan mengabaikan kemajuan sifat SDM-nya.

\section{Pembahasan}

Faktor-faktor Pendorong perubahan, Ada 2 Perubahan yang dilakukan didalam restoran Barasenja tersebut yakni faktor internal dan eksternal antara lain:

1. Eksternal

a. Teknologi

Organisasi tidak dapat mengabaikan peningkatan inovasi teknolagi yang semakin cepat. kemajuan inovasi baru membawa perubahan dalam kemampuan, pekerjaan, desain dan budaya. jadi organisasi harus secara konsisten mengikuti perubahan teknologi agar tidak tertinggal. Organisasi jasa sebaiknya semakin meningkatkan penggunaan teknologi yang canggih sebagai alat untuk memperbaiki produktivitas dan market competitiveness.Teknologi informasi berdampak kuat dengan adanya plikasi yang beragam untuk mendukung aktifitas organisasi .bagaimanapun organisasi harus mengikuti tren atau kebiasaan yang sedang berkembang yang berdampak positif. Dalam hal ini Bara senja telah melakukan pembaharuan untuk mendukung kelancaran transaksi, dan pelayanan. Sperti pemesanan via gojek,grabfood, pesan dari rumah agar memudahkan konsumen. Banyak masyarakat di era digital sudah menggunakan dompet elektronik untuk memenuhi 
kebutuhan tersebut organisasi akan berupaya memberikan solusi pembayaran lewat dompet digital,seperti dana contohnya.

a. Perubahan pasar

Untuk menjadi organisasi yang bersaing, organisasi harus bereaksi cepat untuk menampilkan/ kebutuhan konsumen, dengan lasan bahwa pasar selalu berubah secara progresif dan membutuhkan perbaikan yang dapat diterima. Seorang pemimpin yang cerdas akan secara konsisten berusaha untuk tampil didepan para pesaingnya. akibatnya organisasi harus mengubah cara berhubungan dengan konsumen. organisasi yang tidak dapat memenuhi selera pasar atau konsumen akan ditinggalkan. Seperti menerapkan 3S ( senyum, sapa, salam), berusaha seminim mungkin agar waktu tunggu makan tidak membosanan, menyediakan wifi, music, tempat keagamaan. Menjaga kebersihan baik (meja konsumen,dapur, serta kebersihan produk)

b. Karakteristik geografis

Untuk memperbaiki kesalahan sebelumnya organisasi melakukan perubahan dari segi karakteristik geografis, sperti menentukan batasan umur karyawan dari 19-25 tahun, penempatan keryawan disesuaikan dengan keahliannya,dengan begitu jelas karyawan bisa berkontribusi penuh terhadap kinerjanya.

2. Internal

a. Munculnya peralatan baru

Munculnya peralatan baru dengan teknologi berlangsung secara cepat dan mempengaruhi cara kerja karyawan.teknologi ini diharapkan membuat organisasi semakin kompetitif contohnya mesin printer otomatis, dan mesin press, tempat penyimpanan minuman, dan tempat penyimpanan bahan makanan.

b. Sikap karyawan

Untuk menhindari adanya ketidak puasan karyawan organisasi harus menyelesaikan masalah tersebut dengan berbagai pendekatan 
dalam merancang pekerjaa, konflik( mengevaluasi terhadap kendala karyawan), ambiguitas, peran , organisasi mampu menghargai dan memberikan penghargaan atas pekerjaan mereka dengan memberi bonus. perubahan tersebut bertujuan untuk meminimalisisr konflik hingga saat ini.(Sw, 2013)

\section{$\underline{\text { Tujuan }}$}

Visi

Membuka lebih dari 100 cabang di seluruh indonesia, menjadi brand atau merek nasional, mampu membuka lebih banyak lapangan pekerjaan, menjadi market leader untuk kategori makanan berjenis nasi goreng.

Misi

Memiliki superteam dan manajemen yang professional, mendaftar dan tersertifikasi di Haki, memiliki sistem dan standar operasional prosedur yang sangat baik, terus mengeluarkan menu makanan dan minuman yang berbeda dari competitor, mempunyai brand identity yang kuat, mengetahui kelebihan dan kekurangan brand dengan seksama, memiliki segementasi pasar yang jelas, mampu melakukan promosi konvensional dan digital secara rutin dan efektif.

Tujuan pengadaan perubahan pada organisasi ini adalah untuk memperbaiki kemampuan :

a) Organisasi dapat beradaptasi dengan baik terhadap perkembangan pasar dan kemajuan teknologi.

b) Untuk mengidentifikasi jenis dan aspek perubahan yang dibutuhkan perusahaan.

c) Pengembangan produk dan mencari inovasi

d) Menciptakan proses kerja yang efisien dan akurat.

e) Alat identifikasi pertumbuhan melalui customer(Tampubolon, 2020) 
Hambatan dalam melakukan perubahan Bara Senja yakni dari segi :

1. Demografi

Dimana semakin bertambah penduduk akan bertambahnya kebutuhan dengan adanya perkembangan teknologi dan komunikasi dan keinginan dari konsumen yang beragam. Semakin banyak penduduk maka banyak kebutuhan yang akan dipenuhi jika organisasi yang tidak melihat jangka perubahan maka jadi hambatan suatu perubahan.

2. Persepsi terhadap revolusi informasi

Restoran Barasenja akan tertinggal jika tidak mengikuti jalannya revolusi informasi. Hambatan ini terjadi jika persepsi terhadap perkembangan organisasi menganggap sebagi sesuaitu yang menkautkan ketika perannya digantikan oleh teknologi informasi.

3. Lingkungan \& social

Kemajuan teknologi tidak menjamin perhatian cukup kepada masalah keadilan dan adanya dampak peningkatan konsentrasi pendapatan atau kesenjangan yang akan menimbulkan masalah social. Disini organisasi harus memperhatikan lingkungan dan social, dan memberikan kesejahteraan kepada masyarakat banyak

\section{Planed change ( perubahan terencana)}

Didalam resto Barasenja ada beberapa perubahan terencana yang dilakukan ada 3 meliputi: Merencanaan perbaikan manajemen, penambahan staff dan pematangan SOP.

\section{Daftar pustaka}

Sw, S. (2013). Peranan Manajemen Perubahan dalam Pertumbuhan Organisasi. Journal of Chemical Information and Modeling, 53(9), 1-7.

Tampubolon, M. P. (2020). Change Management Manajemen Perubahan: Individu, Tim Kerja Organisasi. 